\title{
Örgütsel İletişim ve Örgütsel Vatandaşlık Davranışının Lojistik Yetenek Üzerindeki Etkisi ${ }^{1}$
}

\author{
Burcu ERŞAHAN \\ Prof. Dr., Kahramanmaraş Sütçü İmam Üniversitesi, \\ İktisadi ve İdari Bilimler Fakültesi, Uluslararası Ticaret ve Lojistik Bölümü \\ bersahan@hotmail.com \\ Orcid ID: https://orcid.org/0000-0003-2546-0567

\section{İsmail BAKAN} \\ Prof. Dr., Kahramanmaraş Sütçü İmam Üniversitesi, \\ İktisadi ve İdari Bilimler Fakültesi, İşletme Bölümü \\ ibakan63@hotmail.com \\ Orcid ID: https://orcid.org/0000-0001-8644-8778
}

\section{Makbule OĞUZ}

Kahramanmaraş Sütçü İmam Üniversitesi, Sosyal Bilimler Enstitüsü Doktora Öğrencisi makbule-oguzz@hotmail.com

Orcid ID: https://orcid.org/0000-0002-4612-7387

\section{Öz}

İletişim sosyal yaşam için vazgeçilmez bir unsur olduğu kadar, örgütsel hedeflerin yerine getirilmesinde de önemli bir rol oynamaktadır. Örgütsel iletişim, örgütler için elzemdir. Örgütsel iletişim, belirli hedef ve işlevlerini yerine getiren örgütlerin gelişmesine yarar sağlar. İşgörenlerin iş ortamında bağlantılı olduğu çalıșma arkadaşlarıyla kurdukları ilişkileri ve iletișimleri örgütün başarısının yükselmesi hususunda önemlidir.

Örgütsel iletişim ve örgütsel vatandaşlık davranışı bir örgütün verimliliğinin yükseltilmesi ve geliştirilmesinde çok önemli bir yere sahip unsurlardır. $\mathrm{Bu}$ unsurların yetersizliği, örgütün temel yapı taşlarından biri olan insan kaynăg 1 potansiyelinin azalmasına yol açmaktadır. Bu bilgiler ışı ğında örgüt içerisinde bir bütünlüğün ve düzeninin sağlanması, müşteri ihtiyaçlarını doğru zamanda, doğru

\footnotetext{
${ }^{1}$ Makale Geliş/Kabul Tarihi: 26.08.2020 / 12.10.2020

Künye Bilgisi: Erşahan, B., Bakan, İ. ve Ŏguz, M. (2020). Örgütsel İletişim ve Örgütsel Vatandaşlık Davranışının Lojistik Yetenek Üzerindeki Etkisi. Kahramanmaraş Sütçü Imam Üniversitesi Sosyal Bilimler Dergisi, 17 (2), 1050-1078. DOI: $10.33437 / \mathrm{ksusbd} .785846$
} 
yerde ve doğru fiyat politikasıyla hareket ederek rekabet avantaj1 elde edebilmek için örgütün lojistik yetenekleri üzerine yatırım yapması gerekmektedir. $\mathrm{Bu}$ yatırımlar sayesinde örgütün performansı artabilecektir. Bu bilgilere bağlı olarak araştırmanın temel amacı da lojistik firmalarda çalışan işgörenlerin örgütsel iletişim algıları ve örgütsel vatandaşlık davranışlarının lojistik yetenek üzerindeki etkisini incelemektir. Bu amaca ulaşabilmek için araştırma verileri anket tekniği ile elde edilmiştir. Anketler İstanbul'da faaliyet gösteren lojistik firmalarında çalışan 301 işgörene uygulanmıştır. Anket verilerinin analizi SPSS ve Mplus istatistik programında yapılmıştır. Analizler sonucunda örgütsel iletişim ve örgütsel vatandaşlık davranışı algılarının, lojistik yetenek alt boyutları üzerinde olumlu etkisi olduğu bulgusuna ulaşılmıştır.

Anahtar Kelimeler: Örgütsel İletişim, Örgütsel Vatandaşlık Davranışı, Lojistik Yetenek, Lojistik İnovasyon, Lojistik Hizmet Farklılı̆̆1.

\title{
The Impact of Organizational Communication and Organizational Citizenship Behavior on Logistics Ability
}

\begin{abstract}
Communication is an indispensable element for social life as well as playing an important role in meeting organizational goals. Organizational communication is essential for organizations. Organizational communication benefits the development of organizations that fulfill their specific goals and functions. The relationships and communications that employees establish with their colleagues in the business environment are important for the success of the organization.

Organizational communication and organizational citizenship behavior are elements that have a very important place in increasing and developing the efficiency of an organization. The insufficiency of these elements leads to a decrease in the human resource potential, which is one of the basic building blocks of the organization. In the light of this information, it is necessary to invest in the logistics capabilities of the organization in order to ensure integrity and order within the organization, to achieve competitive advantage by acting on customer needs at the right time, at the right place and with the right price policy. Thanks to these investments, the performance of the organization can increase. Based on this information, the main purpose of the study is to examine the impact of organizational communication perceptions and organizational citizenship behaviors of employees working in logistics companies on logistics ability. In order to achieve this aim, research data were obtained by survey technique. The
\end{abstract}


surveys were applied to 301 employees working in logistics companies operating in Istanbul. The analysis of the questionnaire data was made in SPSS and Mplus statistical program. As a result of the analysis, it was found that organizational communication and organizational citizenship behavior perceptions have a positive effect on logistics ability sub-dimensions.

Keywords: Organizational Communication, Organizational Citizenship Behaviour, Logistics Ability, Logistics Innovation, Logistics Service Differences.

\section{GíRIŞ}

Bütün insan ilişkilerinin vazgeçilmez bir unsuru olan iletişim, sadece insanlar için değil örgütler için de örgütün devamlılığı ve bütünlüğü açısından mühim bir unsurdur. İletişim, örgütsel yapı içindeki durumu gereği diğer unsurlardan daha karmaşık bir yapıdadır. Örgütsel öğeler arasındaki yüksek dayanışma ve koordinasyon, personel arasındaki ahenk ve iyi ilişkilere temel oluşturan iletişime bağlidır. Bu ahenk ve ilişkileri yani etkin iletişimi sağlamak, hem örgütsel etkinliği arttıracak hem de üretim ya da hizmet sunum sürecini meydana getiren elemanlar arasında kuvvetli bir bağ oluşturacaktır (Halis, 2000:218).

Günümüze gelindiğinde, örgütler insan odaklı bir yönetim anlayışını benimsemiş ve bu da beraberinde iletişim olgusunun öne çıkmasına sebep olmuştur. Örgüt ve işgören üzerinde önemli etkileri olan iletişim, örgütün etkinliğinin yanı sıra yöneticilerin başarısında büyük rol oynayan bir süreçtir ve bu sürecin etkin bir şekilde yönetilmesi gerekmektedir (Çöllü ve Summak, 2010:278).

Örgütün amaçlarını yerine getirebilmesi için örgütün kaynaklarını etkin ve verimli bir şekilde kullanması gerekmektedir. Örgütün kaynaklarından en önemlisi de insan kaynağıdır. İnsan kaynağı yani işgörenlerin örgütün faaliyetlerini benimsemesi, kendisini örgüt için değerli bir kaynak olarak görmesi ile belirlenen amaçlara ulaşmak planlanan süreden daha kısa zamanda olacaktır. İşgörenlerin kendilerinden istenilen işlerden daha fazlasını ortaya çıkarması örgütsel vatandaşlık davranışının temelini meydana getirmektedir. İşgörenlerin örgütsel vatandaşlık davranışı gösterebilmeleri için örgüt içerisinde yönetici ve işgörenler arasında kurulacak iletişim çok önemli bir yer tutmaktadır. Örgütsel iletişimin etkin bir şekilde yerine getirilememesi işgörenin iş tatminini düşürecektir.

Örgütlerin verimliliklerinin ve performanslarının artması göstermiş oldukları örgütsel vatandaşlık davranışına bağlıdır. Ayrıca örgütlerin rekabet avantajı elde edebilmesi, öğrenen örgüt olabilmesi ve çevresine entegre olabilmesi örgütlerin 
sahip olduğu iletişim seviyesine bağlıdır (Altunbaş, 2009:2). Yine aynı şekilde lojistik inovasyon ve lojistik hizmet farklılığı kavramları da örgütlerin rekabet avantajı elde edebilmesinde oldukça önemli bir rol oynamaktadır. Örgütsel vatandaşlık davranışı ve örgütsel iletişim kavramlarıyla ilgili bazı çalışmalar yapılmıştır. Örgütsel iletişim ve örgütsel vatandaşlık davranışı kavramlarını ele alan araştırmacılar, Demirel ve arkadaşları (2011), örgütsel iletişim ile örgütsel vatandaşl1k davranışı, Akpolat ve Turgut (2017) örgütsel vatandaşlık ve örgütsel özdeşleşme, örgütsel sessizlik, Taşliyan ve Hrrlak (2014) örgütsel iletişim etkinliği, iş tatmini, örgütsel bağl1lık ve örgütsel vatandaşlık davranışı kavramlarını ele almıştır. Fakat örgütsel iletişim ve örgütsel vatandaşlık davranışı kavramları ile lojistik inovasyon ve lojistik hizmet farklılı̆̆ arasındaki etkiye ve ilişkiye yönelik çalışmanın olmadığı literatür incelemesinde tespit edilmiştir. Örgütsel iletişim ve örgütsel vatandaşlık davranışı kavramları her alanda olduğu gibi lojistik alanında da çok önemlidir. Bu çalışma ile literatürde tespit edilen boşluğun doldurabileceği ve kavramların ilk kez birlikte ele alınması sebebi ile önemli olduğu düşünülmektedir.

\section{ÖRGÜTSEL ILETIŞIM, ÖRGÜTSEL VATANDAŞLIK DAVRANIŞI VE LOJISTIK YETENEK KAVRAMLARINA TEORİK YAKLAŞIM}

Çalışmanın bu bölümünde örgütsel iletişim, örgütsel vatandaşl1k davranış1 ve lojistik yetenek kavramları teorik olarak açıklanmıştır.

\section{Örgütsel İletişim}

İletişim kavramı, Latince bir kavram olan Communicare'den türetilmiştir. Anlamı, ortak kılmak demektir. İletişim, bireylerin kendi iç dünyasında başlayıp bireylerarası, takım ve örgütlerin genelinde, kitlesel bir biçimde, teknolojik seviyede olmak üzere yaşamın tüm alanlarında karşımıza çıkmaktadır (Karaçor ve Şahin, 2004: 99). İletişim kısaca, birey-birey, birey-grup, birey-toplum, grupgrup, grup-toplum ve toplumlar arasındaki doğal veya düzenlenmiş yaşayış amaçları doğrultusunda karşılıklı ilişki ve etkileşimdir (Aşkun, 2016:2). Yönetici bakımından iletişim ise, örgütün hedeflerini yerine getirmek ve örgütün işleyişini sağlamak için planlama, yöneltme, örgütleme, eşgüdümleme ve kontrol gibi yönetim fonksiyonlarını sağlamaya yönelik örgüt içi ve örgüt dışı fikir alışverişinin yürütülmesidir (Geçikli, 2004:108). İletişim yalnızca yöneticinin değil bütün örgütün başarısında önemli bir rol oynar. Bu sebeple, örgütsel anlamda iletişim tanımına bakılacak olunursa, örgütleri neredeyse bir sinir ağ 1 gibi saran, hayati öneme sahip bir öğe olarak örgütlerde saptanan hedeflere ulaşabilmek için bir bilginin bir bireye veya daha fazla gruba resmi veya resmi olmayan yollarla iletilmesi ve yayılması sürecidir (Bakan vd., 2019:2228). Örgütsel iletişim, örgüt işgörenlerinin birbirleriyle olan iletişimlerini veya örgüt adına diğer ortaklarla kurdukları iletişimin tamamını içermektedir. İletişim, 
örgütün bir bütün olmasını sağlayan ve varlığının devamı için vazgeçilmez bir parçadır (Eroğlu, 2010:30). Çoğunlukla bilgi aracılığıyla iki ya da daha fazla kişinin tutumlarını değiştirme, davranışlarına etkide bulunma süreci olarak ortaya çıkmaktadır (Kelly, 2000:92). Örgütsel iletişim, örgütteki bir bilginin, fikir veya düşüncenin bir bireyden başka bir bireye veya bireylere, direkt olarak sözlü, yazılı veya sözsüz kanallardan direkt olmadan teknoloji aracıllğıyla (telefon, bilgisayar vs.) iletilme ve alınması sürecidir (Bakan ve Büyükbeşe, 2004:3). Örgütsel iletişim sürecinde kaynak ile hedef kitle arasında mesajın niteliğini kaybetmeden ulaşması gerekmektedir (Demir ve Demir, 2009:68). İletişim süreçleri boyutunda iletişim biçimi, zamanlama ve tavır ön plana çıkmaktadır. Çoğu örgütlerde resmi olmayan iletişim biçimi tercih edilirden, bazı örgütlerde resmi ve bürokratik tarz kullanılır (Ertekin vd., 2017:302). Örgütsel iletişim örgüt çalışanlarının ve müşterilerin örgüte yönelik, duygu düşünce ve fikir algısını şekillendiren; örgütün aynası niteliğinde olan ve itibarı besleyen süreçlerden biridir ve planlı bir çabayı gerektirir (Van Riel ve Fombrun, 2007:25).

Örgütsel iletişim kavramıyla ilgili yapılan tanımlara ve açıklamalara bakıldığında şu sonuçlara ulaşmak mümkündür (Atak, 2005:60):

- Örgütsel iletişim, bireylerin bir araya gelmesine yardımcı olan bir güçtür. Örneğin, bir firma kuracak kişinin, kuracağ 1 firma ile ilgili düşüncelerine ortak olabilecek veya katılabilecek bireyleri bulması gerekmektedir. Bunun oluşabilmesi için de etkin bir iletişim gücü gerekmektedir.

- Örgütsel iletişim, ortak bir hedef çerçevesinde toplanan bireylerin işbirliğini ve entegrasyonunu sağlayan birleştirici bir süreçtir.

- Örgütsel iletişim, örgütün çevresiyle uyumlu olmasına yardımcı olan bir süreçtir.

- Örgütsel iletişim kavramı; örgüt yönetimi tarafından tespit edilen bir işleyiş olduğu gibi, örgütteki bireylerin sosyal ve psikolojik ihtiyaçlarına bağlı olarak meydana gelen, programlanmamış iletişim paylaşımlarının bulunduğu doğal bir görünümü de yansitmaktadır.

Örgüt içi iletişim için gerekli olan, ulaşılmak istenilen hedefleri gerçekleştirmek ve işgörenlerin beklendiği biçimde çalışmalarını sağlamaya yardımc1 olmaktadır. Örgütsel iletişim üst düzey yöneticilerin, onlara bağlı çalışanların, orta düzey yöneticilerin ve diğer çalı̧̧anların kurum içinde birbiriyle iletişim kurma biçimini ifade etmektedir (Grunig, 2005:15). Eğer örgüt içi iletişim iyi kurulamaz ise, örgüt işgörenleri faaliyetlerini birbirlerinden bağımsız ve kopuk bir şekilde yerine getirmeye çalışır. Bu da örgütsel hedeflere ulaşmayı bazen imkansiz hale getirirken, bazen ise daha fazla zaman ve daha fazla emek harcamayı gerektirebilir (Eroğluer, 2011:123). 
İletişimin doğru bir şekilde yönetilmesi, işgörenlerin örgütsel vatandaşlik davranışını pozitif yönde etkilemektedir. Buna bağlı olarak örgütsel iletişimde tatmin sağlamak için yöneticilerden beklenen davranışlar şu şekilde olmalıdır (Demirel vd., 2011:43):

- Örgütsel iletişim kanallarını açık tutmalı ve iletişime geçerlilik kazandırmalıdırlar.

- Örgütsel bilgi paylaşımını arttırmak için iletişimin ne kadar önemli olduğuna vurgu yapmalıdırlar.

- Örgütsel iletişimi kullanmanın ehemmiyetini örgüt politikası haline getirmelidirler.

- Örgütsel vatandaşlık davranışı hareketi gösteren işgörenlerin bu hareketlerini pekiştirecek teşvik politikaları oluşturmalıdırlar.

- İşgörenlerin belirlenmiş rol gereklerinin dışına çıkarak gösterdikleri vatandaşlık davranışlarını geliştirecekleri ortamı sağlamalıdırlar.

- Örgütsel başarının işgörenler arası iletişim ve işbirliğine dayandığını vurgulamalıdırlar.

- İşgörenler arası iletişim ile vatandaşlık davranışlarını geliştirecek örgütsel kültür değerlerini güçlendirmelidirler.

Örgütsel iletişime özellikle ihtiyaç duyulan hususlar ise aşağıdaki şekilde ifade edilebilir (Koontz vd.,1986.; Akt: Güllüoğlu, 2012:22).

- Örgüt amaçlarını yayma ve yerleştirme,

- Örgütün başarısı için planlar geliştirme,

- İnsan ve diğer kaynakları en etkili ve verimli biçimde organize etme,

- İnsanların katkıda bulunmak isteyeceği bir iklim yaratma ve

- Performansi kontrol etme.

Yapılan literatür taramasında örgütsel iletişim ile ilgili yapılmış bir çok araştırmaya rastlanılmıştır. Halis (2000) tarafından örgütsel iletişim ve iletişim tatminine ilişkin bir çalışma yapılmıştır. Araştırma sonucunda örgütsel iletişim başarısının ve iletişim tatmininin yaş, eğitim ve cinsiyete bağlı olarak değişeceği, bireylerin kendilerini kurumun çok önemli bir parçası olarak algılamalarında örgütsel iletişim politikalarının ne kadar önemli olduğu bulgularına ulaşılmıştır. 
Eroğluer (2011), örgütsel iletişim ile iş tatmini unsurları arasındaki ilişkiler üzerine bir araştırma yapmıştır. Araştırma sonucunda iş tatmin boyutlarından yönetici, işin niteliği ve ücret boyutlarında örgütlerin çalışanların beklentilerine yönelik uygulamalar yapması iş tatmin seviyelerini olumlu yönde arttırabileceği bulgusuna ulaşı1mıştır. Elmas ve Karabulut (2018)'un 'örgütsel iletişimin iş tatmini üzerindeki etkisi: otomotiv sektöründe bir araştırma" isimli çalışmalarında örgütsel iletişimin boyutları olan iletişim biçimlerinin ve eğitici iletişimin iş tatminini pozitif yönde etkilediği sonucuna varmışlardır. Bakan ve arkadaşları (2019), örgütlerde iletişim tarzının çalışanların muhalif davranışları üzerindeki etkisine ilişkin bir araştırma yapmışlardır. Sonucunda ise, yöneticilerin, örgütlerde söz sahibi olan bireylerin, çalışanlardan gelen görüşlere karşı açık olup onlardan fayda sağlayabileceklerinin farkına varmaları ve böylece politika ve uygulamalarını iyileştirebileceklerinin mümkün olduğu bulgusuna ulaşılmıştır.

\section{Örgütsel Vatandaşlık Davranışı}

Örgütsel vatandaşlık davranışı, ilk kez 1983 yılında işletme yönetimi yazınına girmiş ve son yılların temel araştırma konularından birisi olmuştur. Bu davranış farklı açılardan incelenmiş ve başka davranışlar üzerindeki etkileri yapılan araştırmalarla ortaya konulmuştur. O zamandan beri, yazarlar (Bateman ve Organ, 1983; Katz, 1964; Katz ve Kahn, 1966; Organ, 1977; Roethlisberger ve Dickson, 1939) örgütsel hayatta kalma için resmi rol gereksinimlerinin ötesine geçen bireysel çabaların gerekli olduğunu kabul etmişlerdir (Akt: Walz ve Niehoff, 2000:307) Örgütsel vatandaşlık davranışı kavramı "biçimsel ödül sistemine dikkat etmeden, organizasyonun fonksiyonlarını bir bütün olarak verimli bir şekilde yerine getirmesine yardımcı olan, gönüllülük esasına bağlı birey davranışı" olarak ifade edilebilir (Organ, 1988; Akt: Özdevecioğlu, 2003: 118). Yine, Organ (1988) örgütsel vatandaşlık davranışlarını "karşl1ıksız olan ve toplamda bir organizasyonun etkin işleyişini teşvik eden ekstra rol davranışları" olarak tanımlamıştır (Van Dick vd., 2006: 284). Örgütsel vatandaşlık davranışı kavramını ekstra rol davranışı olarak tanımlayan Bateman ve Organ (1983); şekilsel kurallar sınırında belirtilen, tanımlanmayan ve işgörenlerin isteklerine bağlı şekillenen davranışlar olarak nitelemişlerdir. Örgütsel vatandaşl1k davranışı, işgörenlerin iş tanımlarında belirtilen görev, davranış ve rollerinin dışında isteyerek çalışma, gönüllü olma ve daha çok gayret ve azim gösteren davranış şekilleri olarak tanımlanabilir (Avc1, 2015: 13). Örgütsel vatandaşlık davranışı, işgörenlerin kendi görevleri dışında, kendi istekleriyle oluşan, örgütlerin resmi ödül sistemlerinde direkt olarak tanımlanmayan, kişisel davranışlardır. İşgörenler kendilerini yaptıkları işe adarlar. Kendilerini işe adayınca, örgütün ilerlemesine, başarılı olmasına ve daha iyiye gitmesine katkı sağlayacaklarına inanırlar (Nezakati, 2010:48). Örgütsel vatandaşlık davranışı, işgörenlerin çok fazla görev bilincine sahip olmalarıdır. İşgörenlerin görev ve 
sorumluluklarının dışında yer alan örgütsel vatandaşlık davranışı, örgüte zarar verecek davranışlardan koruma, işgörenlerin fikirlerini dikkate alma, işgörenlerin yeteneklerini geliştirmelerini sağlama ve etkin bir iletişim ağı oluşturma gibi faaliyetlerle alakalıdır (Sabuncuoğlu ve Tüz, 2016: 302). Örgütsel vatandaşlık davranışı sergileyen işgören, samimi ve içinden gelerek işini yaptığı için dışsal bir ödül beklentisi içinde olmaz. Örnek verilecek olursa, bir işgören mesai saati dolmasına rağmen kendisinden böyle bir şey talep edilmediği halde, iş çıkışında uzun süre örgütte kalarak bitirmesi gereken işleri tamamlamaya çalışıorsa veya kendi resmi iş tanımının bir parçası olmadığı halde, işini bitirmekte zorluk çeken bir takım arkadaşına yardım ediyorsa, bu işgörenin örgütsel vatandaşlık davranışında bulunduğu söylenebilir (Sezgin, 2005:320).

İşgörenlerin örgütsel vatandaşlık davranışı gösterme sebepleri aşağıdaki şekilde özetlenebilir (Gürbüz, 2006:54);

- İşgörenler örgüt ortamında mevcut uygulama ve süreçlerden tatmin oldukları sürece, yöneticilerin sergilemiş oldukları adaletli ve eşit davranışlar, işgörenin örgüte ve yöneticilerine karşı pozitif bir tutum sergilemesine neden olacak ve bunun sonucu olarak da işgörenler örgütsel vatandaşlık davranışı gösterebileceklerdir.

- Psikolojik sözleşme gereği işgören örgütte pozitif ilişki kurar ve örgütün faydasına davranış sergiler. Bu davranışlar örgütsel sadakat, şeflerine tevafuk ve işbirliğine yönelik davranışlarından olabilecektir. İşgören yüksek katılım seviyesine sahipse ve psikolojik sözleşmeyi pozitif yönde algıllyorsa yüksek derecede bir örgütsel vatandaşlık davranışı göstermesi beklenebilir.

- İşgören göstereceği iş performansı sonucunda sosyal onay olarak kendisini kabul ettireceğine inanırsa örgütsel vatandaşlık davranışı sergileyebilecektir.

- İşgörenler ortaya koyacağı pozitif ve gönüllü davranışların ileride karşılıksız kalmayacağına, kariyer aşamaları süresince sergilediği örgütsel vatandaşlık davranışının kendisine ödül veya terfi getireceğine inanırsa örgütsel vatandaşlık davranışı sergileyebilecektir.

- İşgören iş tanımını tam anlamıyla bilmiyorsa ya da örgütsel vatandaşlık davranışını iş tanımlarında yerine getirmesi gereken görev ve sorumluluklardan biri olarak algılıyorsa örgütsel vatandaşlık davranışında bulunabilecektir.

- İşgören sahip olduğu kültür, değer yargıları ve inançlarından dolayı içinden geldiği için, bir beklenti içinde olmadan iyilik yapmak amaciyla örgütsel vatandaşlık davranışı sergilemek isteyebilecektir. 
Örgütsel vatandaşl1k davranışı, işgörenlerin örgütsel yaşamda iş tatminleri, motivasyon seviyeleri, performansları ve örgütsel bağlılıklarıyla yakından alakalıdır. İşgörenlerin örgütsel vatandaşlık davranışı yükseldikçe örgütteki bir işi başarma seviyesi de artacaktır. İşgörenin iş başarma seviyelerinin artması, yöneticiler için örgütün amaçlarına ulaşması bakımından önemlidir (Özdevecioğlu, 2013:119). Fakat işgörenlerin örgütsel vatandaşlık davranışını gerçekleştirebilmesi için, işgörenleri bu hususta teşvik edici, karşıllklı etkileşim halinde olma ve bilgi alış-verişinin değerli olduğu bir örgüt ikliminin olması gerekmektedir. $\mathrm{Bu}$ sebeple, yöneticiler işgörenlerin örgütsel vatandaşl1k davranışı göstermelerini destekleyerek güçlü bir örgüt iklimi oluşturabilmektedir. $\mathrm{Bu} \mathrm{da}$, işgörenler arasındaki iletişimi, bilgi alış-verişini, yardımlaşmayı ve paylaşmayı kolaylaştırmaktadır. Örgütsel vatandaşlık davranışı, işgörenlerin temel iş gereksinimlerinin dışında, işgörenin isteğine bağlı olarak gösterdiği örgüt davranışları kümesi olarak adlandırılır. Genellikle görev sorumluluğunun ötesine geçen davranışlar olarak ifade edilir (Jahangir vd., 2004:75).

Örgütsel vatandaşlık davranışının örgüte ve işgörenlere sağladığı yararlardan k1saca bahsedilecek olursa (Acar, 2006:12);

- İşgörenlerin ve örgütlerin etkinliğini, verimliliğini yükseltir.

- Örgütsel kaynakların daha etkin bir şekilde kullanılmasına yardımcı olur.

- Örgüt içerisinde oluşturulmuş olan ekiplerin faaliyetlerinin koordine edilmesini sağlayan kaynak rolünü üstlenir.

- Örgütün iş yaşamında oluşabilecek her türlü değişim ve gelişmelere kolayca adapte olmasını sağlar.

- İşgörenin ve örgütün performansını yükseltir.

- Örgütteki çalışma ortamının daha çekici bir hal almasını ve örgüt için daha faydalı, yetenek ve kabiliyeti yüksek işgörenlerin işe alınmasını sağlar.

Örgütsel vatandaşlık kavramı ile ilgili yapılan çeşitli araştırmalar literatürde yer almaktadır. Bolat ve Bolat (2008), otel işletmelerinde örgütsel bağlllık ve örgütsel vatandaşlık davranışı ilişkisi üzerine yapmış oldukları çalışmada, örgütsel bağl11ık ve boyutlarının örgütsel vatandaşlık davranışı üzerinde olumlu bir etkiye sahip olduğu sonucuna ulaşmışlardır. Örgütsel bağl1lık düzeyi arttıkça, işgörenler de sosyal mübadelenin bir karşılığ 1 olarak daha fazla örgütsel vatandaşlık davranışı göstermektedirler. Demirel ve arkadaşları (2011), örgütsel iletişim ile örgütsel vatandaşlık davranışı arasındaki ilişki üzerine bir araştırma yapmışlardır. Araştırma sonucunda, çalışanlar arası güçlü iletişimin varlığının örgütsel vatandaşlık davranışını geliştirdiği ve güçlendirdiğini dikkate alan 
örgütlerin daha başarılı ve etkin olacaklarını ifade etmişlerdir. Çelik ve Çıra'nın (2013) örgütsel vatandaşlık davranışının iş performansı ve işten ayrılma niyeti üzerine etkisinde aşırı iş yükünün aracılık rolü isimli çalışmalarında çalışanların sergiledikleri örgütsel vatandaşlık davranışının iş performansını artıracağına ve işten ayrılma niyetlerini düşüreceğine yönelik bulgular tespit etmişlerdir.

\section{Lojistik Yetenek}

Günümüzde başka sektörlerde olduğu gibi lojistik sektöründe de öğrenen örgüt organizasyon yapısının ve inovasyonun değeri gün geçtikçe artmaktadır. Lojistik sektörü devamlı olarak değişim ve gelişim göstermektedir. Örgüt için bilgiye ulaşmak oldukça kıymetlidir. Fakat bunun yanı sıra örgüt içinde bilginin nasıl kullanılacağı ya da nasıl paylaşılacağını da öğrenmek ana husustur. Lojistik firmaları bilgiyi ortaya çıkarmayı, örgüt içinde bilgileri paylaşmayı ve örgütün geleceklerini inşa etmeyi hedeflemektedirler.

Lojistiğin kapsamı ve etkisi 1940'ların sonunda gelişmiştir. 1950'lerde ve 60'larda, lojistik kullanan tek örgüt askeriye idi. Lojistik kapsamı rekabet gücünün geliştirilmesi için önemli araçlardan biri olarak kabul edildiğinden ordunun ötesine genişletilmiştir (Burda, 2015: 170).

Cecilia (2010), lojistiği "hammadde, yarı mamul, mamul mallar ve ilgili bilgilerin başlangıç noktasından tüketim noktasına kadar verimli, uygun maliyetli akış ve depolanmasını planlama, uygulama ve kontrol etme süreci” olarak tanımlamaktadır (Akt: Karaxha ve Kristo, 2016: 38). Philip Kotler ise lojistiği, "müşterinin ihtiyacını yararlı bir şekilde karşılamak için başlangıç noktasından kullanım noktasına malzeme ve bitmiş malların fiziksel akışlarını planlama, uygulama ve kontrol etme” olarak tanımlar (Business Management Ideas, 24.02.2020, www.businessmanagementideas.com).

Lojistik yetenek, bir firmanın tüm varlık, yetkinlik, organizasyonel süreçler, firma nitelikleri, bilgi, tecrübe gibi verimliliğini ve etkinliğini artıran stratejileri tasarlamasına ve uygulamasına olanak sağlayan bir parçasıdır (Barney, 1991; Akt. Cho vd., 2008: 337). Hayes ve Pisano (1994), bir firmanın lojistik yeteneğinin müşteri beklentilerini aşan, piyasa ve finansal performansı artıran önemli parametrelerden biri olarak algılandığını belirtmiştir.

Lojistik yeteneği yüksek olan firmalar, sahip oldukları yetenekleri sayesinde müşterileri ile daha sağlam bir ilişki kurarak onların firmaya olan sadakatlerini yükselmekte ve ürün maliyetlerini düşürerek kar seviyesini arttırmakta; bu sayede de rekabet avantaj1 elde etmektedirler (Bakan ve Şekkeli, 2015: 398). Firmaların rekabet avantajı ve üstün karlar elde edebilmeleri için hem maliyet avantaji yaratabilmesi hem de rakiplerine oranla farklılaşabilmesi lojistik yeteneklerini etkin bir şekilde kullanmasıyla mümkündür. Yurt dışından Zara, 
Wal-Mart ile ülkemizde Arçelik'in üstün firma performansı yaratan ve taklit edilmesi zor lojistik yetenekleri, adı geçen firmaların rekabet avantajı elde etmelerinde oldukça fazla etkileri olmuştur (Acar, 2010: 5). Zara, Wal-Mart ve Hewlett Packard gibi şirketler rakiplerine karşı stratejik bir silah olarak kullanılan ortak üstün lojistik sistemlerine sahiptir (Sandberg ve Abrahamsson, 2011: 62). Lojistik yetenek iki alt boyuttan oluşmaktadır. Lojistik yetenek kavramı açılandıktan sonra konunun daha iyi anlaşılabilmesi için lojistik yetenek alt boyutları olan lojistik inovasyon ve lojistik hizmet farklılığ açıklanacaktır.

\section{Lojistik İnovasyon}

Lojistik, ürünlerin teslim süresi, ürünün değeri, örgütün güvenilirliği ve müşteri hizmetlerine etkide bulunur. Lojistiğin hedefi, olabildiğince hızlı dağıtım yapmak, maliyetleri azaltmak, verimi artırmak ve stokları azaltmakla beraber nihai amaç müşteriyi tatmin seviyesine ulaştırabilmektir. İnovasyon kavramına yönelik literatürde çok farklı tanımlar yer almaktadır. İnovasyon Latince'de yenileme anlamına gelen "innovatus" kelimesinden türetilmiştir ve yeni ve değişik bir sonuç elde edilmesi manasında kullanılmaktadır (Elçi, 2006: 1). İnovasyon kavramı, firmalarda ürün ve hizmet kalitesinin yükseltilmesinde, küresel pazarda faaliyet gösterilmesinde ve maliyetlerin düşürülmesi hususlarında fayda sağlamaktadır (Uzun, 2001: 190). Lojistik inovasyon yeteneği kavramı ise, rekabet avantaj1 yaratabilmek, daha çok verim elde edebilmek ve karını yükseltebilmek için; firmaların sundukları plan, strateji, program, yöntem, taşıma modu, maliyet yönetimi, stok kontrolü, bilişim teknolojileri gibi lojistik hizmetlerinde değişiklik yaratabilme marifetidir (Bakan ve Şekkeli, 2015: 402403). İnovasyon, lojistik firmalar da dahil olmak üzere birçok firmanın başarısı için kritik öneme sahiptir.

Lojistik inovasyon kavramını ilk kez ortaya çıkaran Flint ve arkadaşları (2005: 114) tarafindan lojistik inovasyon; "bir odak grubuna yeni ve faydalı görünen, baştan sona kadar herhangi lojistik ile alakalı hizmet" olarak ifade edilmiştir. Kısacası, Flint vd. lojistik inovasyonu tüketiciler için özgün iyileştirmeler, gelişmeler ve inovasyonu içinde barındıran katma değerli lojistik faaliyetler olarak tanımlamışlardır.

Lojistik inovasyonun ticaret yaşamındaki değer yükselişi yakın zamanda meydana gelmiştir. İnovasyonun değerinin anlaşılmasına müteakip, bütün sektörlerde olduğu gibi, lojistik sektöründe de inovatif fikirlerin ele alınması için araştırmalar yapılmıştır. İnovasyonun lojistik sektörüne olan pozitif etkileri sektörün önde gelen örgütlerinin inovasyon uygulamalarından anlaşılmaktadır. Dünyanın en büyük lojistik şirketi olarak bilinen UPS, ayrım ve online takibin öncüsüdür (Aksungur ve Bekmezci, 2018:72). 


\section{Lojistik Hizmet Farklılıkları}

Küreselleşmeyle birlikte lojistik, firmalar için yeni pazarlara ulaşabilmek, daha fazla üretim ve kaynak verimliliği elde edebilmek için dahası firmaların tedarik zinciri boyunca malzeme ve ürünlerin nakliyesinde giderek daha kilit bir rol oynayacaktır. Artan rekabet ortamında, lojistik sağlayıcılar (firmalar), lojistik hizmetlerini müşterilerine maliyet, kalite ve katma değer açısından nasıl konumlandırmak istediklerini belirlemek için bir strateji belirlemelidirler (Sum ve Teo, 1999:588).

Ekonomik ilişkilerin ve dünya ticaret hacminin artmasına bağlı olarak uluslararasındaki bağımlılık gün geçtikte artmakta ve firmalar için lojistik hizmet farklılıkları mühim bir olgu olarak ortaya çıkmaktadır. Firmaların rekabet avantajı elde edebilmeleri için, lojistik yeteneklerin analizlerini iyi bir şekilde yapmaları ve firmaların lojistik sürece adapte olmaları gerekmektedir (Kozan, 2019: 20).

Müşterilerin önemli gördüğü lojistik teklifleri sağlama süreci lojistik hizmet farklılığı olarak ifade edilmektedir. Lojistik hizmet farklılığında karar alma sürecinde firmaların lojistik hizmet sunumunu farklılaştırıp ayırmayacağı, farklılığın nasıl yapılması gerektiğine karar verilir. Sürecin bir sonucu olarak, hizmet stratejisi seçimi yapılır ve stratejinin uygulanması için farklılaşma alternatifleri tasarlanır. Lojistik hizmet farklılığı dokuz aşamalı bir karar verme sürecinden oluşmaktadır (Şekil 1) (Pirttilä ve Huiskonen,1996:132,135). 


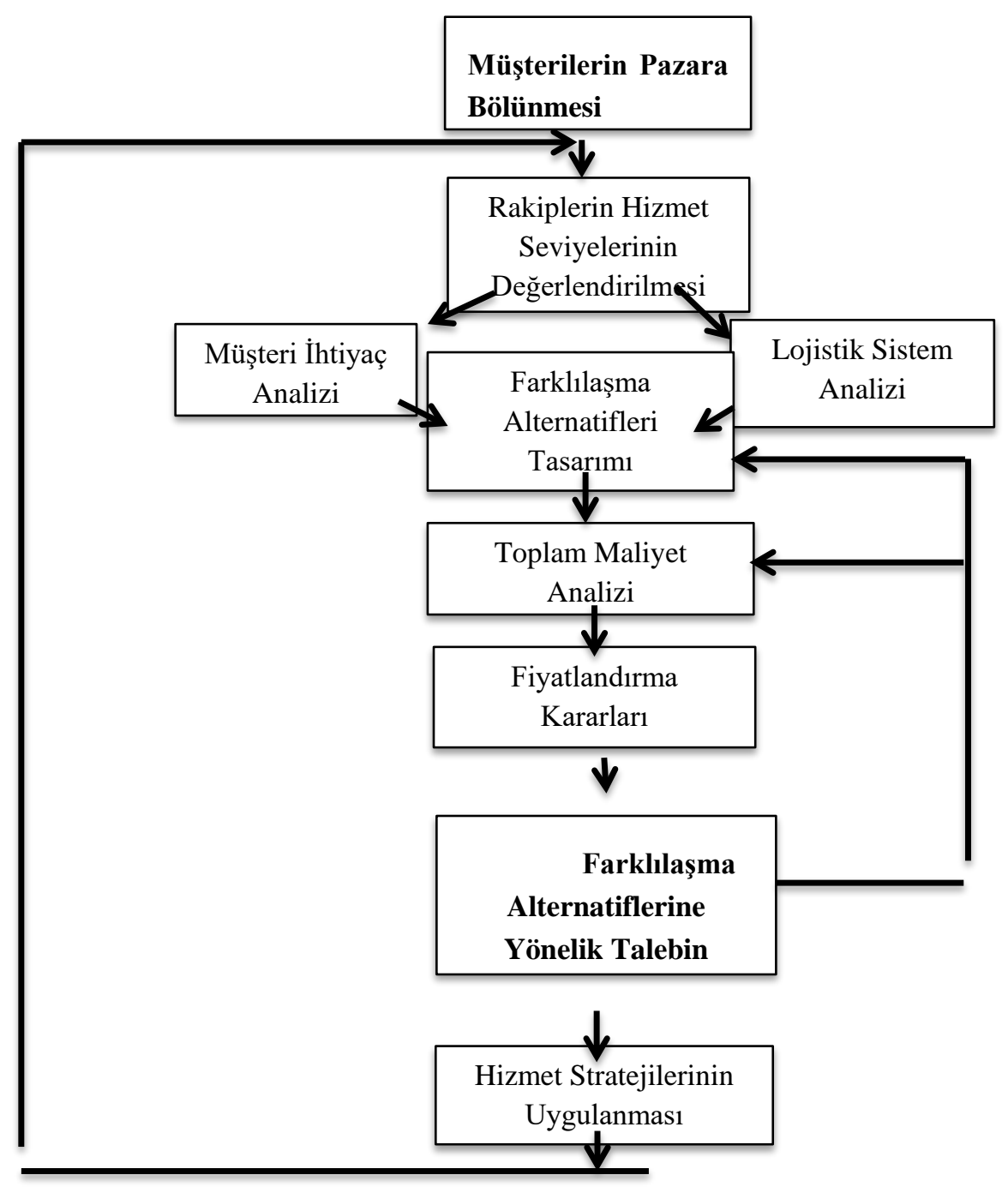

Şekil 1. Lojistik Hizmet Farklılı̆̆ının Karar Verme Süreci Kaynak: Pirttilä ve Huiskonen,1996:132

Lojistik hizmet farklılığı incelendiğinde, firmalar avantaj sağlamak adına lojistiği bir yetenek olarak kullanabilmek için yollar aramaktadırlar. Firmalar kendilerini rakiplerinden farklı k1lan yetenekleri belirlemeye ve uygulamaya çalışmaktadır (Day, 1994:39). 
B. Erşahan-İ. Bakan-M. Oğuz Örgütsel İletissim ve Örgütsel...

\section{ARAŞTIRMANIN METODOLOJISİ}

\section{Araştırma Yöntem}

Teknolojideki baş döndürücü değişim lojistik sektörüne de tesir etmektedir. Rekabet koşullarından dolayı, lojistik firmaların artan tüketici taleplerine cevap verebilmeleri, pazardaki konumlarını güçlendirebilmeleri için inovatif şekilde kendilerini geliştirmeleri gerekmektedir. Bu gelişimin tamamlanabilmesi için örgüt içerisinde çalışan işgörenlerin göstermiş oldukları davranışlar önem arz etmektedir. $\mathrm{Bu}$ araştırmada, örgütsel iletişim ve örgütsel vatandaşlık davranışı kavramlarıyla lojistik yetenek alt boyutları arasındaki ilişkiler ele alınmıştır. $\mathrm{Bu}$ araştırmanın temel amacı, örgütsel iletişim ve örgütsel vatandaşlık davranışının, lojistik yetenek alt boyutları olan lojistik inovasyon ve lojistik hizmet farklılı̆̆ 1 üzerindeki etkisini incelemektir. Araştırma evreni ve örneklemi belirlenirken Ulusal Nakliyeciler Derneğinin 2018 yılında yayınladığı verilerinden faydalanılmıştır. $\mathrm{Bu}$ verilere göre İstanbul'da faaliyet gösteren 307 lojistik firması bulunmaktadır. 307 lojistik firmasında çalışan işgörenler araştırmanın evrenini oluşturmaktadır. Bu evren üzerinden $\mathrm{n}=\mathrm{N} . \mathrm{z} 2 . \sigma 2 /(\mathrm{N}-1) . \mathrm{H} 2+\mathrm{z} 2 . \sigma 2$ formülü kullanılarak örneklem sayısı tespit edilmiştir (Ural ve Kılıç, 2013: 3545). Bu formülde yer alan $\mathrm{N}$ : evren büyüklügü̈; $\mathrm{n}$ : örneklem büyüklüğ̈̈; $\sigma$ : standart sapma değeri; $\mathrm{H}$ : standart hata değeri; $\mathrm{Z}$ : belirli bir $\alpha$ anlamlılık düzeyine karşılık gelen teorik değer anlamına gelmektedir. Yüzde 95 güven aralı̆̆ 1 $(\mathrm{z}=1,96), 0,05$ örneklem hatas1 $(\mathrm{H}), 0,5$ standart sapma $(\sigma)$ ile 307 evren büyüklüğü $(\mathrm{N})$ değerleri için araştırma kapsamında ele alınması gereken örneklem sayısının 171 lojistik firmasında çalışan işgören olması gerektiği tespit edilmiştir. Araştırma kapsamında ise basit tesadüfi örnekleme yöntemi ile seçilen 350 işgörene anketler elden dağıtılmış olup çalışma sonunda kullanılabilir anket sayıs1 301 olarak gerçekleşmiş̧ir. Anket soruları, ilgili literatürden türetilmiş olup, anket formunda açık ve kapalı uçlu soruların yanında Likert tarzı önermelere de yer verilmiştir. Anket formunda yer alan Lojistik İnovasyon kavramını ölçmeye yönelik Anderson ve West (1998) tarafından geliştirilen 5 sorudan oluşan ölçek kullanılmış ve ölçekte yer alan ifadelerin uyarlanmış halinin kontrolü uzman akademisyenler tarafından sağlanmıştır. "Lojistik çalışanlarımız açık ve değişime duyarlıdır" , "Lojistik çalışanlarımız yeni fikirlerin uygulanmasında yardımcı olacak kaynakları sağlamakta ve paylaşmaktadırlar" gibi önermeler ölçekte yer alan önermelerden birkaçıdır. Araştırmanın diğer değişkeni olan lojistik hizmet farklılı̆̆ kavramını ölçmeye yönelik Lynch ve arkadaşları (2000) tarafından geliştirilen 4 sorudan oluşan ölçek kullanılmıştır. "Lojistik hizmetlerimiz, iş ortaklarımıza diğer firmalarla yapamayacakları bir şeyleri yapmalarını sağlar", "Rakip firmalara kıyasla, dağıtım hizmetlerimiz müşteriye benzersiz özellikler veya nitelikler sunar" gibi önermeler ölçekte yer alan önermeler arasındadır. Araştırmanın üçüncü değişkeni olan örgütsel vatandaşlık davranışı kavramını ölçmeye yönelik Organ ve Konovsky (1989) 
tarafından geliştirilen 19 sorudan oluşan ölçek kullanılmıştır. "İşletmemizde iş arkadaşlarının iş yerinde olmadığı zamanlarda onların işlerine yardım edilir", "İşletmemizde çalışanlar üzerinde etki yaratan kararlar alınırken çalışanların görüşlerine de başvurulur", "İşletmemizde çalışanlar toplantılara katılır ve görüş bildirirler" gibi önermeler örgütsel vatandaşlık davranışı ölçeğinde yer alan ifadelerden bazılarıdır. Araştırmanın son değişkeni olan örgütsel iletişim kavramını ölçmeye yönelik Milles ve arkadaşları (1996) tarafından geliştirilen 24 sorudan oluşan ölçek kullanılmıştır. "Yöneticim iş dışındaki ilgi alanlarımla, hobilerimle ilgilenir", "Yöneticim işin nasıl yapılacağı hakkında görüşlerimi sorar", "Yöneticim yaptığım işi başkalarının önünde eleştirmez" gibi önermeler örgütsel iletişim ölçeğinde ifade edilen önermeler arasındadır. Ankette yer alan önermeler 1: "Kesinlikle Katılmıyorum, 2:Katılmıyorum, 3: Kararsızım, 4: Katılıyorum ve 5: Kesinlikle Katılıyorum" şeklinde 5'li Likert ölçeği ile ölçülmüştür. Toplanan anketler aracılığıyla elde edilen verilerin değerlendirilmesinde SPSS ve Mplus istatistik programları kullanılmıştır. Araştırma hipotezleri regresyon analizi ve yapısal eşitlik modeli ile test edilmiştir.

\section{Araştırmanın Modeli}

$\mathrm{Bu}$ araştırmada, örgütsel iletişim ve örgütsel vatandaşlık davranışının (bağımsız değişken), lojistik inovasyon ve lojistik hizmet farklılı̆̆ 1 (bağımlı değişken) üzerindeki etkisini inceleyen bir model esas alınmış olup model Şekil 2'de görülmektedir. Modelde, örgütsel iletişim ve örgütsel vatandaşlık davranış1 yüksek olan işgörenlerin firmalarında daha yenilikçi lojistik davranış göstereceği ve lojistik hizmet farklılığına daha duyarlı davranacağ 1 görüşü savunulmaktadır.

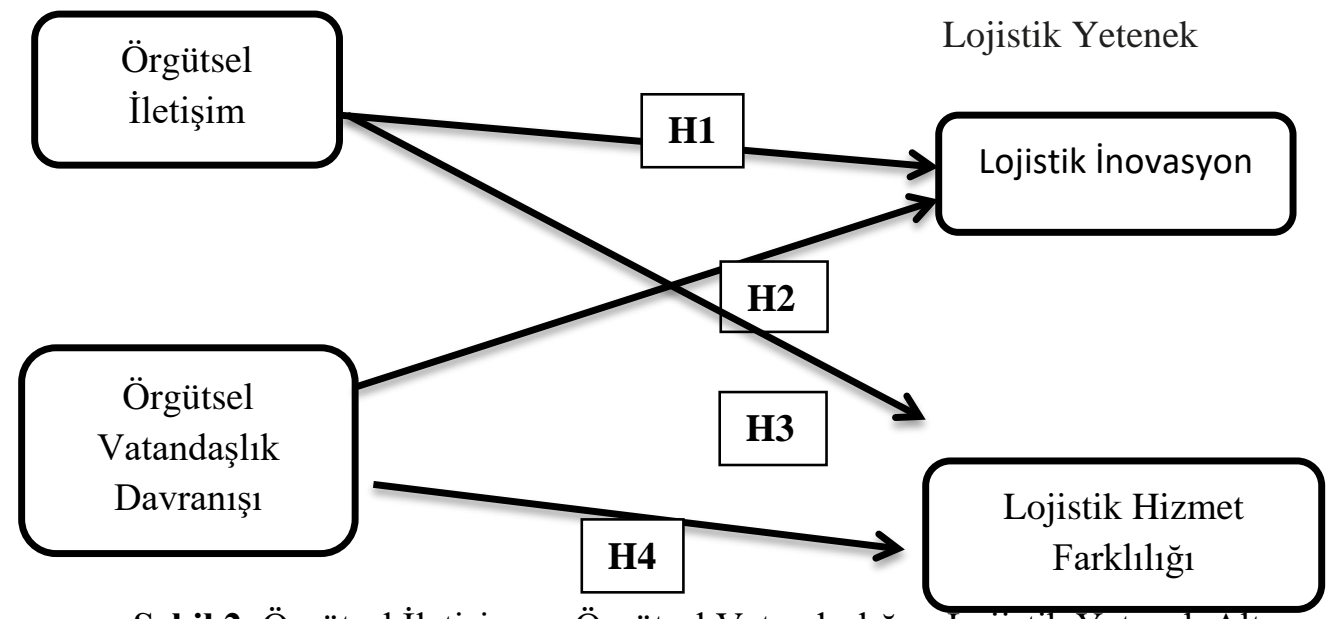

Şekil 2. Örgütsel İletişim ve Örgütsel Vatandaşlığın, Lojistik Yetenek Alt Boyutları Üzerindeki Etkisi Modeli 
Araştırma modelinden hareketle oluşturulan hipotezler şunlardır:

H1: Örgütsel iletişim, lojistik yetenek alt boyutlarından lojistik inovasyonu olumlu yönde etkilemektedir.

H2: Örgütsel vatandaşlık davranışı, lojistik yetenek alt boyutlarından lojistik inovasyonu olumlu yönde etkilemektedir.

H3: Örgütsel iletişim, lojistik yetenek alt boyutlarından lojistik hizmet farklılığını olumlu yönde etkilemektedir.

H4: Örgütsel vatandaşlık davranışı, lojistik yetenek alt boyutlarından lojistik hizmet farklıı̆ı̆ını olumlu yönde etkilemektedir.

\section{Araştırma Bulguları}

Araştırma değişkenlerinin güvenirliliği literatürde yaygın olarak kullanılan Cronbach Alfa değerleri ile ölçümlenmiştir. Tablo 1'de yer alan lojistik inovasyon, lojistik hizmet farkl1lıkları, örgütsel vatandaşlık davranışı ve örgütsel iletişim değişkenlerinin güvenilirlik düzeylerinin, Kayış (2014)'ın yüksek derecede güvenilir olarak tanımladığı 0,80 ve üzerinde olduğu tespit edilmiştir.

Tablo 1. Araştırma Değişkenlerinin Güvenilirliği

\begin{tabular}{|l|l|l|}
\hline \multicolumn{1}{|c|}{ Değişkenler } & $\begin{array}{l}\text { Cronbach Alfa } \\
\text { Değeri }\end{array}$ & $\begin{array}{l}\text { Önerme } \\
\text { Sayıları }\end{array}$ \\
\hline Lojistik İnovasyon &, 945 & 5 \\
\hline Lojistik Hizmet Farklılıkları &, 931 & 4 \\
\hline Örgütsel Vatandaşlık &, 980 & 19 \\
\hline Örgütsel İletişim &, 985 & 24 \\
\hline
\end{tabular}

Ankete katılanların cinsiyet, yaş, medeni durum, firmadaki görev, meslekteki çalışma süresi gibi demografik değişkenlere göre durumları Tablo 2'de sunulmuştur.

Tablo 2. Araştırmaya Katılan Çalışanların Demografik Özellikleri

\begin{tabular}{|l|l|l|l|}
\hline Değişkenler & Gruplar & N & \% \\
\hline Cinsiyet & Kadın & 122 & 40,5 \\
& Erkek & 179 & 59,5 \\
& Toplam & 301 & 100 \\
\hline Yaş & $20-25$ & 31 & 10,3 \\
& $26-30$ & 95 & 31,6 \\
\hline
\end{tabular}




\begin{tabular}{|c|c|c|c|}
\hline & $\begin{array}{l}31-35 \\
36-40 \\
41 \text { ve üzeri } \\
\text { Toplam }\end{array}$ & $\begin{array}{l}97 \\
46 \\
32 \\
301\end{array}$ & $\begin{array}{l}32,2 \\
15,3 \\
10,6 \\
100\end{array}$ \\
\hline $\begin{array}{l}\text { Medeni } \\
\text { Durum }\end{array}$ & $\begin{array}{l}\text { Evli } \\
\text { Bekâr } \\
\text { Toplam }\end{array}$ & $\begin{array}{l}173 \\
128 \\
301\end{array}$ & $\begin{array}{l}57,5 \\
42,5 \\
100\end{array}$ \\
\hline $\begin{array}{l}\text { Eğitim } \\
\text { Durumu }\end{array}$ & $\begin{array}{cl}\text { Lise } & \text { ve } \\
\text { Öncesi } & \\
& \text { Ön Lisans } \\
& \text { Üniversite } \\
& \text { Lisansüstü } \\
& \text { Toplam } \\
\end{array}$ & $\begin{array}{l}22 \\
44 \\
169 \\
66 \\
301\end{array}$ & $\begin{array}{l}7,3 \\
14,6 \\
56,1 \\
21,9 \\
100\end{array}$ \\
\hline Görev & $\begin{array}{c}\text { İthalat- } \\
\text { İhracat } \\
\text { Satış- } \\
\text { Pazarlama } \\
\text { Lojistik } \\
\text { Saha } \\
\text { Çalışanı } \\
\text { Operasyon } \\
\text { Toplam }\end{array}$ & $\begin{array}{l}73 \\
57 \\
59 \\
62 \\
50 \\
301\end{array}$ & $\begin{array}{l}24,3 \\
18,9 \\
19,6 \\
20,6 \\
16,6 \\
100\end{array}$ \\
\hline $\begin{array}{r}\text { Meslekte } \\
\text { Çalışma Süresi }\end{array}$ & \begin{tabular}{lll} 
& \multicolumn{1}{l}{ 1 Yıldan az } \\
& $1-5$ yıl & \\
& $6-10 y ı l$ & \\
& 11 yıl ve \\
üzeri & & \\
& Toplam & \\
\end{tabular} & \begin{tabular}{l|l}
47 \\
140 \\
82 \\
32 \\
301
\end{tabular} & $\begin{array}{l}15,6 \\
46,5 \\
27,2 \\
10,6 \\
100\end{array}$ \\
\hline $\begin{array}{l}\text { Örgütün } \\
\text { Lojistik Sektöründe } \\
\text { Faaliyet Gösterme } \\
\text { Süresi }\end{array}$ & $\begin{array}{l}0-3 \text { yıl } \\
4-7 \text { yll } \\
8-11 \text { yıl } \\
12-14 \text { yll } \\
15 \text { ve üstü } \\
\text { Toplam }\end{array}$ & \begin{tabular}{l|l|}
3 \\
11 \\
69 \\
97 \\
121 \\
301 \\
\end{tabular} & $\begin{array}{l}1,0 \\
3,7 \\
22,9 \\
32,2 \\
40,2 \\
100\end{array}$ \\
\hline $\begin{array}{r}\text { Mesleği } \\
\text { Sevme Durumu }\end{array}$ & $\begin{array}{l}\text { Evet } \\
\text { Hayır } \\
\text { Toplam }\end{array}$ & $\begin{array}{l}227 \\
74 \\
301\end{array}$ & $\begin{array}{l}75,4 \\
24,6 \\
100\end{array}$ \\
\hline
\end{tabular}

Araştırma anketi toplamda $122(\% 40,5)$ kadın, $179(\% 59,5)$ erkek işgörenler tarafindan yanıtlanmıştır. Katılımcıların 173'ü bekâr, 128'i evli seçeneğini işaretlemiştir. Yaş dağılımına bakıldığında ise katılımcıların büyük 
çoğunluğunun $(\% 63,8)$ 26-35 yaş aralığında olduğu görülmektedir. Katılımcıların eğitim durumları hakkında sorulan soruya verdikleri yanttlara bakıldığında, büyük çoğunluğunun $(\% 56,1)$ üniversite mezunu olduğu anlaşılmaktadır. Firmadaki görevleri açısından katılımcıların verdikleri yanıtlara bakıldığında, ithalat-ihracat (\%24,3), satış-pazarlama (\%18,9), lojistik (\%19,6), saha çalışanı $(\% 20,6)$, operasyon $(\% 16,6)$ seçeneklerini işaretledikleri görülmektedir. Yine tablo incelendiğinde katılımcıların \%46,5'inin 1-5 yıl arasında bu meslekte çalıştıkları görülmektedir. Firmanın lojistik sektöründe faaliyet gösterme süresi açısından verdikleri yanıtlara bakıldı̆̆ında, büyük çoğunluğunun $(\% 72,4) 12$ yıldan daha fazla süredir firmaların lojistik sektöründe faaliyet gösterdiğini ifade etmişlerdir. Demografik sorulardan en sonuncusu olan mesleğinizi seviyor musunuz sorusuna 227 katılımc1 "evet" yanıtını vermiştir.

Araştırma hipotezleri test edilmeden önce modelde yer alan değişkenlerin birbirleri ile ilişkilerinin istatistiksel açıdan derecesine bakılmıştır. Değişkenler arası korelasyon analiz sonuçları Tablo 3'te gösterilmiştir.

Tablo 3. Korelasyon Testi Sonuçları

\begin{tabular}{|l|l|l|l|l|}
\hline Değişkenler & 1 & 2 & 3 & 4 \\
\hline $\begin{array}{l}\text { 1.Örgütsel } \\
\text { İletişim }\end{array}$ & 1 & & & \\
\hline $\begin{array}{l}\text { 2.Örgütsel } \\
\text { Vatandaşlık } \\
\text { Davranış1 }\end{array}$ &, $935^{* *}$ & 1 & & \\
\hline $\begin{array}{l}\text { 3.Lojistik } \\
\text { İnovasyon }\end{array}$ &, $844^{* *}$ &, $852^{* *}$ & 1 & \\
\hline $\begin{array}{l}\text { 4.Lojistik } \\
\text { Hizmet } \\
\text { Farkl11ığ1 }\end{array}$ &, $796^{* *}$ &, $813^{* *}$ &, $805^{* *}$ & 1 \\
\hline
\end{tabular}

Örgütsel iletişim, örgütsel vatandaşlık davranışı, lojistik inovasyon ve lojistik hizmet farklılığı arasındaki ilişki, korelasyon analizi ile test edilmiştir. Tablo 3 'te yer alan korelasyon analizi sonuçlarına göre örgütsel iletişim, örgütsel vatandaşlık davranışı, lojistik inovasyon ve lojistik hizmet farklılığı arasında anlamlı ve pozitif ilişki olduğu tespit edilmiştir. Örgütsel iletişim ile lojistik inovasyon arasındaki ilişki $(, 844) \mathrm{p}<.01$ düzeyinde anlamlı tespit edilirken örgütsel iletişim ile lojistik hizmet farklılığ 1 arasındaki ilişki $\left(, 796^{* *}\right) \mathrm{p}<.01$ düzeyinde anlamlı pozitif tespit edilmiştir. Örgütsel vatandaşlık davranışı kavramı ile lojistik inovasyon arasındaki ilişki $(, 852) \mathrm{p}<.01$ düzeyinde anlamlı bulunurken örgütsel vatandaşlık davranışı ile lojistik hizmet farklılı̆ğ arasındaki 
ilişki $(, 813) \mathrm{p}<.01$ anlamlı ve pozitif olarak tespit edilmiştir. Dolayısıyla korelasyon analizi sonuçları araştırmanın hipotezlerini doğrular yöndedir.

Çalışmada geliştirilen hipotezleri test etmek amacıyla yapılan regresyon analizi Tablo 4 ve Tablo 5'te sunulmuştur.

Tablo 4. Örgütsel İletişim ve Örgütsel Vatandaşlık Davranışının Lojistik İnovasyon Üzerindeki Etkisi

\begin{tabular}{|c|c|c|c|c|}
\hline $\begin{array}{c}\text { Bağımsız } \\
\text { Değişkenler }\end{array}$ & Standart Hata & $\beta$ & $\mathrm{T}$ & Sig. \\
\hline Sabit Say1 &, 103 &, 533 & 5,160 &, 000 \\
\hline $\begin{array}{c}\text { Örgütsel } \\
\text { İletişim }\end{array}$ &, 077 &, 352 & 4,563 &, 000 \\
\hline $\begin{array}{c}\text { Örgütsel } \\
\text { Vatandaşl1k }\end{array}$ &, 079 &, 477 & 6,044 &, 000 \\
\hline $\mathrm{R}^{2}=, 744, \quad$ DüzeltilmişR ${ }^{2}=, 742$ & $\mathrm{~F}=432,226, \quad$ Sig $=, 000$ \\
\hline
\end{tabular}

Bağımlı Değişken: Lojistik İnovasyon

Araştırmada geliştirilen "Örgütsel iletişim (H1) ve örgütsel vatandaşlık (H2) davranışının, lojistik yetenek alt boyutlarından lojistik inovasyonu anlamlı ve olumlu yönde etkilemektedir" hipotezlerini test etmek amaciyla yapılan regresyon analizi sonucuna göre; örgütsel vatandaşlık davranışının lojistik inovasyonu $(\beta=, 477 ; \mathrm{T}=6,044) \mathrm{p}<0,01$ düzeyinde anlaml, pozitif yönde etkilediği görülmektedir. Örgütsel iletişim ise lojistik inovasyonu $(\beta=, 352$; $\mathrm{T}=4,563) \mathrm{p}<0,01$ düzeyinde anlamlı, pozitif yönde etkilediği görülmektedir. Buna bağlı olarak çalışanların örgütsel iletişim ve örgütsel vatandaşlık davranışı arttıkça lojistik inovasyonunda arttığı söylenebilir. Örgütsel iletişim ve örgütsel vatandaşlık lojistik inovasyonun \%77,2'sini açıkladığı anlaşılmaktadır. Bu bilgiler doğrultusunda çalışmanın ilk iki hipotezi (H1 ve H2) kabul edilmiştir.

Tablo 5. Örgütsel İletişim ve Örgütsel Vatandaşlık Davranışının Lojistik Hizmet Farklılığı Üzerindeki Etkisi

\begin{tabular}{|c|c|c|c|c|}
\hline $\begin{array}{c}\text { Bağı̆msız } \\
\text { Değişkenler }\end{array}$ & Standart Hata & $\beta$ & $\mathrm{T}$ & Sig. \\
\hline Sabit Say1 &, 129 &, 529 & 4,104 &, 000 \\
\hline $\begin{array}{c}\text { Örgütsel } \\
\text { İletişim }\end{array}$ &, 096 &, 294 & 3,052 &, 002 \\
\hline $\begin{array}{c}\text { Örgütsel } \\
\text { Vatandaşl1k }\end{array}$ &, 099 &, 575 & 5,824 &, 000 \\
\hline $\mathrm{R}^{2}=, 671, \quad$ DüzeltilmişR ${ }^{2}=, 668$ & $\mathrm{~F}=303,430, \quad$ Sig=,000 \\
\hline
\end{tabular}

Bağımlı Değişken: Lojistik Hizmet Farklılığı 
Çalışmada örgütsel iletişim ve örgütsel vatandaşlığın lojistik hizmet farklılığı üzerindeki etkisini test etmek amacıyla yapılan regresyon analizi sonucu Tablo 5 'de verilmiştir. Örgütsel vatandaşlığın lojistik hizmet farklılığını $(\beta=, 575 ; \mathrm{T}=$ $5,824) \mathrm{p}<0,01$ düzeyinde anlamlı ve pozitif etkilediği görülmektedir. Örgütsel vatandaşlık davranışı arttıkça lojistik hizmet farklılığ 1 artmaktadır. Çalışmada lojistik hizmet farklılı̆̆ını etkileyen diğer değişken ise örgütsel iletişimdir. Tablo 5 'de görüldüğü üzere örgütsel iletişim lojistik hizmet farklılığını $(\beta=, 294 ; \mathrm{T}=$ $3,052) \mathrm{p}<0,01$ düzeyinde anlamlı ve pozitif etkilemektedir. Korelasyon analizi sonuçları da bu bulguyu desteklemektedir. Bu verilere göre araştırmanın 3. ve 4 . Hipotezleri olan "Örgütsel iletişim (H3) ve örgütsel vatandaşl1k (H4) davranışının, lojistik yetenek alt boyutlarından lojistik hizmet farklılığını anlamlı ve olumlu yönde etkilemektedir" hipotezleri kabul edilmiştir.

\section{Yapısal Eşitlik Modeli}

Çalışmada örgütsel iletişim, örgütsel vatandaşlığın lojistik inovasyon ve lojistik hizmet farklılığı üzerindeki etkisini tespit etmek için geliştirilen araştırma modelini test etmek amacıyla yapısal eşitlik modeli oluşturulmuştur. Kurulan yapısal eşitlik modeli M Plus yazılımı kullanılarak test edilmiştir.

Yapısal eşitlik modeli birbiriyle alakalı iki basamaktan meydana gelmektedir. İlk basamakta, gözlemlenen değişkenlerle örtük değişkenler arasındaki ilişkileri gösteren ölçüm modelinin araştırılması yapılmaktadır. Diğer basamakta ise, farklı örtük değişkenler arasındaki ilişkilerin ortaya çıkarıldığı yapısal modelin araştırılması gerçekleşmektedir. Elde edilen model ile verilerin uyumluluğu, çeşitli uyum indekslerine göre değerlendirilmiştir. Tablo 6'da model uyumunun değerlendirilebilmesi için literatürde kabul görmüş uyum iyiliği istatistiklerinin değer aralıkları verilmiştir.

Tablo 6. Uyum Ölçütleri ve Sınırları

\begin{tabular}{|c|c|c|}
\hline Uyum Ölçütleri & İyi Uyum & Kabul Edilebilir Sınır \\
\hline$\chi^{2 / / d f}$ & $0<\chi^{2 / / \mathrm{df}} \leq 2 \mathrm{sd}$ & sd $\quad 2 \mathrm{sd}<\chi 2 / / \mathrm{df} \leq$ \\
\hline $\mathrm{p}$ değeri & $0.05 \leq \mathrm{p} \leq 1.00$ & $0.01 \leq p \leq 0.05$ \\
\hline RMSEA & $0 \leq \mathrm{RMSEA} \leq 0.05$ & $0.05 \leq \mathrm{RMSEA} \leq 1.00$ \\
\hline TLI & $\leq 1.00 \quad 0.95 \leq$ TLI & $0.90 \leq \mathrm{TLI} \leq 0.95$ \\
\hline CFI & $0.95 \leq \mathrm{CFI} \leq 1.00$ & $\begin{array}{ll} & 0.90 \leq \mathrm{CFI} \leq \\
0.95 & \end{array}$ \\
\hline
\end{tabular}

(Ventura, 2011; Yalçın ve Fidan, 2011:125; Şimşek, 2007:14; Meydan ve Şeşen, 2011:37; Bayram, 2010:72-78 Kenny, 2010; Çokluk vd., 2010:271-272, Akt: Eyitmiş, 2016:149) 
Örgütsel iletişim, örgütsel vatandaşlığın lojistik inovasyon ve lojistik hizmet farklılığı üzerindeki etkisini belirleyebilmek amaciyla kurulan modele (Model 1) ait veriler Şekil 2'de gösterilmiştir. Modelde yer alan bağımlı değişkenler lojistik yetenek ve lojistik hizmet farklılığı, bağımsız değişkenler ise örgütsel iletişim ve örgütsel vatandaşlık olarak tespit edilmiştir. Sonuçlar Şekil 3'de görülmektedir.

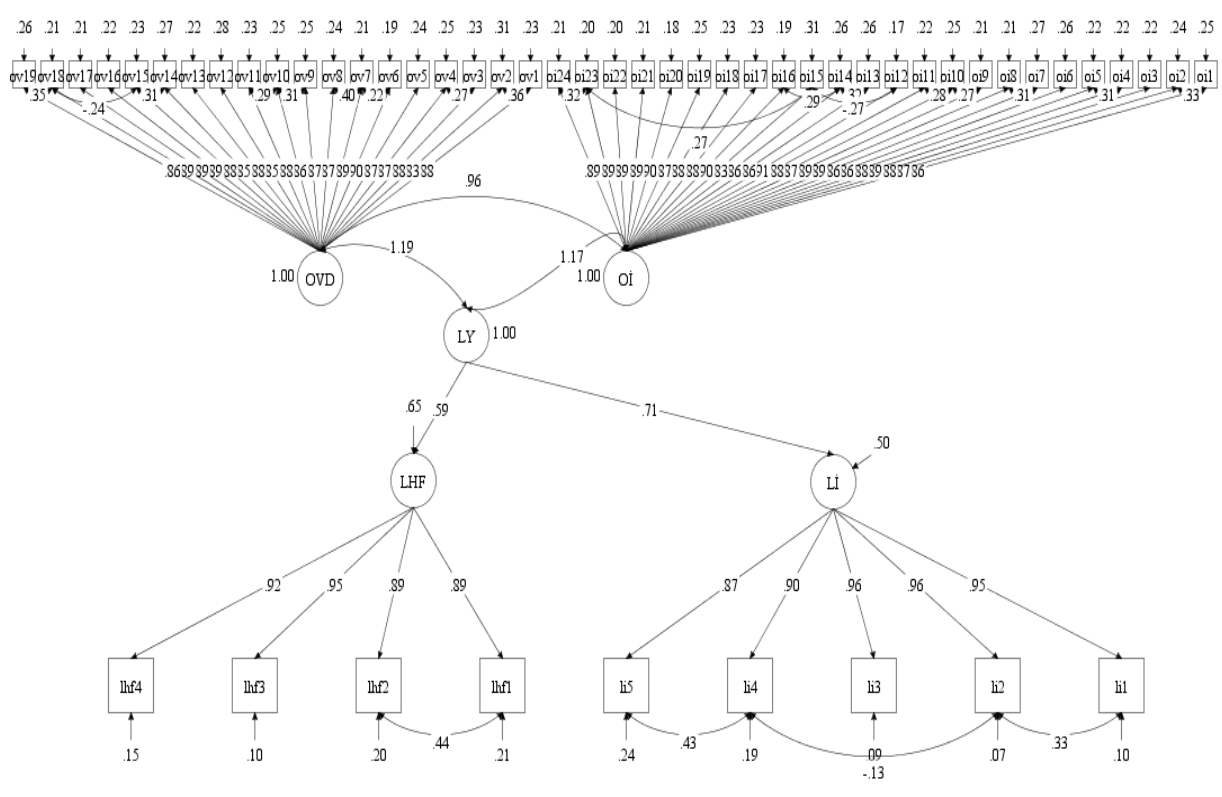

Şekil 3. Örgütsel İletişim, Örgütsel Vatandaşlığın Lojistik İnovasyon ve Lojistik Hizmet Farklılığı Arasındaki İlişki

Model uyum iyilik uyum indeksine bakıldığında CFI değerlerinin 0.90 ve 0.90 'dan büyük olduğu ve RMSEA ve SRMR değerlerinin 0.08 'den küçük olduğu görülmektedir. Dolayısıyla yapısal eşitlik modelleri uyum indeksine göre model kabul edilebilir düzeydedir (Kline, 2011). Yine $\chi^{2} / \mathrm{sd}$ değerinin istenen değer olan 4'ün altında olduğu görülmektedir.

$\chi^{2}(1777)=3294.463 ; \quad \mathrm{CFI}=0,899 ; \quad \mathrm{RMSEA}=0,05 ; \quad \mathrm{SRMR}=0,05$ olup bu verilerden yola çıkarak, araştırma amacına ulaşmak için kurulan, örgütsel iletişim, örgütsel vatandaşlığın lojistik inovasyon ve lojistik hizmet farklılığını olumlu ve istatistiksel olarak anlamlı bir şekilde etkileyeceği modelinin doğrulanmış olduğu ifade edilebilir. 


\section{SONUÇ}

Günümüzde kişilerin işgören olarak rolü tekrardan incelenmekte ve insan kaynağ 1 olarak kabul edilip makinenin bir parçası olmaktan ziyade, üretim ve hizmet sürecini tespit eden, yönlendiren ve düzenleyen bir güç olarak önem kazanmaktadır (Bedük ve Ertürk, 2015:2). Firmaların temel unsuru insanlar olduğundan ve insanlar iletişim yoluyla kendini ifade ettiğinden tüm firmalar için iletişim elzem bir konu olarak ortaya çıkmaktadır. İyi bir iletişim sistemi bulunmayan firmalarda firma içi anlaşmazlıklar, çatışmalar yanında birçok olumsuzluk yaşanabilmektedir.

Örgütler yaşamlarını devam ettirebilmek ve rekabet ortamında lider olabilmek için diğer örgütlerle bir yarış içerisindedir. Örgütün sektörde bulunduğu pozisyonu koruyabilmesi ve daha iyi bir pozisyona yükselmesi çok önemlidir. Bunu gerçekleştirebilmek için örgüt içerisinde güçlü bir iletişimin olması gereklidir. Örgütün hedeflerine ve amaçlarına ulaşmasında veyahut daha iyi bir pozisyonda olmasında etkili olabilecek bir diğer unsur da örgüt içinde sergilenen örgütsel vatandaşlık davranışıdır.

Örgütsel iletişim ve örgütsel vatandaşlık kavramlarıyla ilgili birçok çalışma yapılmıştır. Demirel ve arkadaşları (2011) tarafından örgütsel iletişim ile örgütsel vatandaşlık davranışı arasındaki ilişki araştırılmıştır. Taşlıyan ve Hırlak (2014)'ın yapmış olduğu çalışma da örgütsel iletişim etkinliği ile iş tatmini, örgütsel bağl1lık, örgütsel vatandaşlık davranışı arasındaki ilişki araştırılmış olup, Uslu ve Balc1 (2012) ise ilköğretim okulu öğretmenlerinin örgütsel vatandaşl1k davranışları ile örgütsel iletişim algılarını araştırmıştır. Fakat örgütsel iletişim ve örgütsel vatandaşlık kavramlarıyla lojistik inovasyon ve lojistik hizmet farklılı̆g 1 arasındaki etkileşime ve ilişkiye yönelik çalışmanın olmadığı literatür incelemesinde tespit edilmiştir. Araştırma kapsamında örgütsel iletişim ve örgütsel vatandaşlık algısının lojistik inovasyon ve lojistik hizmet farklıllı̆g 1 üzerindeki etkisini belirlemeye yönelik analizler yapılmıştır. Araştırmamızın temel hipotezleri olan "H1: Örgütsel iletişim, lojistik yetenek alt boyutlarından lojistik inovasyonu olumlu yönde etkilemektedir.", "H2: Örgütsel vatandaşlık davranışı, lojistik yetenek alt boyutlarından lojistik inovasyonu olumlu yönde etkilemektedir.", "H3: Örgütsel iletişim, lojistik yetenek alt boyutlarından lojistik hizmet farklılığını olumlu yönde etkilemektedir.", "H4: Örgütsel vatandaşlık davranışı, lojistik yetenek alt boyutlarından lojistik hizmet farklılığını olumlu yönde etkilemektedir." hipotezleri yapılan analizlerle doğrulanmış ve kabul edilmiştir.

$\mathrm{Bu}$ çalışmanın hipotez sonuçları uyarınca örgütsel iletişim, örgütsel vatandaşl1k gibi kavramların lojistik yetenek üzerinde pozitif bir etkisi olduğu görülmüştür. Bir başka ifade ile etkili bir iletişim ağının ve işgörenlerin 
göstereceği örgütsel vatandaşlık davranışının lojistik yeteneği arttıracă̆ 1 bulgusuna ulaşılmıştır. Böylelikle örgütler kendi yeteneklerinin farkına varmaları ve onları geliştirme yoluna gitmelidirler. Lojistik yeteneklerini geliştirebilmek için gerekli yatırımlar yapılmalı, gerekli görülürse işgörenlere bu konuda eğitimler verilmelidir. Muhtemel tehditler ve firsatlar göz önünde bulundurularak örgütsel açıdan gelişime firsat verilmelidir.

Araştırma bulgularından hareketle bazı önerilerde bulunulabilir. Bunlar;

- Örgüt içerisindeki iletişim kanalları arttırılarak, işgörenler inovasyon konusunda bilgilendirilebilir.

- Örgütün tüm çalışanlarının iletişim teknolojilerinden faydalanması sağlanabilir.

- İşgörenlerin kendilerini geliştirebilecekleri uygun ortamların sayısı çoğaltılabilir.

- Lojistik yeteneklerin geliştirilmesi, personellerin kendilerine güvenmelerini sağlayarak, yetki ve sorumluluklarını arttırarak sürece dahil edilmeleri sağlanabilir.

- Küreselleşmeyle beraber müşteri ihtiyaçları sürekli ve anlık olarak değişmektedir, bu yüzden örgütlerin yeteneklerinin farkında olup buna uygun örgütsel davranışlar sergilemeleri faydalı olur.

- Teknolojinin hızlı gelişimi, bilgisayar ve internet kullanımındaki artış, dijitalleşme, e-ticaret, küreselleşme gibi sebepler ile her sektör değişime uğramaktadır. Lojistik sektörünün de bu değişimi yakından takip edip, ayak uydurması önerilebilir.

Yapılan bu araştırmanın elbette ki bazı sınırlılıkları vardır. Araştırmamıza katılan işgörenlerin ankette yer alan seçenekleri içtenlikle ve olması gerekeni değil de hâlihazırda olanı yanıtlayıp yanıtlamadıkları bilinmemektedir. Ancak yapılan geçerlilik ve güvenilirlik analizi sonuçlarının iyi olması, bu konuyu olabildiğince ortadan kaldırmaktadır. Ayrıca elde edilen bu sonuçlar lojistik sektörünün özelliklerini yansıtmaktadır. Bu nedenle araştırma, belli bir sektörün belirli bir iş kolunda çalışan kişilerin görüşlerini yansıtan bulgulara sahiptir. Araştırma farklı sektörlerde uygulandığında farklı sonuçların alınması muhtemeldir. İstanbul ilindeki işgörenlerin kültürel özellikleri başka illerde farklılık gösterebilir. Gelecekte yapılacak çalışmalarda, farklı sektörlerde üç kavram arasındaki etkinin olup olmadığı incelenebilir, farklı şehirlerde faaliyette bulunan lojistik firmalarında çalışmalar yapılabilir. 


\section{KAYNAKÇA}

Acar, Zafer A. (2006), "Örgütsel Yurttaşlık Davranışı: Kavramsal Gelişimi ile Kişisel ve Örgütsel Etkileri", Doğuş Üniversitesi Dergisi, Cilt.7 Say1:1 ss.1-14.

Acar, Avni. Z. (2010), "Lojistik Yeteneklerin, Strateji-Performans İlişkisi Üzerindeki Rolü: Kobi’ler Üzerinde Bir Saha Araştırması", Atatürk Üniversitesi İktisadi ve İdari Bilimler Dergisi, Cilt 24 Sayı: 4, ss. 1-21.

Akbolat, Mahmut ve Turgut Meryem (2017), “Örgütsel Vatandaşlık Davranışı, Örgütsel Özdeşleşme ve Örgütsel Sessizlik İlişskisine Yönelik Sağlık Çalışanları Üzerine Bir Araştırma”, Hacettepe Sağlık İdaresi Dergisi, Cilt. 20 Say1: 3, ss.357-384.

Aksungur, Mert ve Bekmezci, Mustafa (2018), "Lojistikte İnovasyonun Önemi” IV. Uluslararası Kafkasya-Orta Asya Dış Ticaret ve Lojistik Kongresi, ss. 69-77.

Altunbaş, Abdullah (2009), “Öğretmenlerin Örgütsel Vatandaşlık Davranışları ve Çalışma Değerlerinin Analizi (Altındă̆ İlçesi Örneği)", Yayınlanmış Yüksek Lisans Tezi, Yeditepe Üniversitesi Sosyal Bilimler Enstitüsü, İstanbul.

Aşkun, İnal (2016), “Örgütsel İletişim ve Küçük Grup Boyutları”, Kurgu Anadolu Üniversitesi İletişim Bilimleri Fakültesi Uluslararası Hakemli İletişim Dergisi, Cilt. 4 Sayı:4, ss.1-39.

Atak, Metin (2005), “Örgütlerde Resmi Olmayan İletişimin Yeri ve Önemi”, Journal of Aeronautics and Space Technologies, Cilt. 2 Sayı:2, ss. 59-67.

Avc1, Ahmet (2015), “Örgütsel Vatandaşılı Davranışları: Kavramsal Gelişimi ve Eğitim Örgütleri Açısından Etkileri”, Hasan Ali Yücel Eğitim Fakültesi Dergisi, Cilt: 12-2, Sayı: 24, ss.11-26

Bakan, İsmail -Doğan, İnci Fatma- Urlu, Akif (2019), “Örgütlerde İletişim Tarzının Çalışanların Muhalif Davranışları Üzerindeki Etkisi”, Business \& Management Studies: An International Journal, Cilt. 7, Say1: 5, ss. 2225-2247.

Bakan, İsmail, Şekkeli, Zümrüt. H. (2015), "Lojistik Stratejilerinin Lojistik Yetenekler Üzerine Etkilerine İlişkin Bir Alan Araştırması”, SOBİDER Dergisi, Cilt. 2, Sayı: 5, ss. 398-422. 
Bakan, İsmail ve Büyükbeşe Tuba (2004), “Örgütsel İletişim İle İş Tatmini Unsurları Arasındaki İlişkiler: Akademik Örgütler İçin Bir Alan Araştırması”, Akdeniz İiBF Dergisi, Sayı:7, ss.1-30

Bateman, Thomas. S., ve Organ, Dennis. W. (1983), “Job Satisfaction and The Good Soldier: The Relationship Between Affect and Employee 'Citizenship'”. Academy of management Journal, Cilt. 26, Sayı: 4, ss.587-595.

Bedük, Aykut ve Ertürk Ebru (2015), "Sosyal Mübadele Teorisi Bağlamında Güç Mesafesi ve Örgütsel Adalet Algılamalarının Örgütsel Vatandaşlık Davranışı Üzerindeki Etkisi: Bir Araştırma”, İşletme Bilimi Dergisi, Cilt: 3, Say1: 1, ss. 1-19

Bolat, Oya. İ. ve Bolat, Tamer (2008), “Otel İşletmelerinde Örgütsel Bağlılık ve Örgütsel Vatandaşlık Davranışı İlişkisi”, Balıkesir Üniversitesi Sosyal Bilimler Enstitüsü Dergisi, Cilt: 11, Sayı: 19, ss.75-94.

Burda, Alexandru (2015). "Logistics Role in the Economy", Knowledge Horizons. Economics, Cilt: 7, Say1: 1, ss.170-173

Cecilia Stănciulescu G. (2010), "Importance of Reverse Logistics for Retail”, The Bucharest Academy of Economic Studies Romania.

Cho, Jay-Joong-Kun-John Ozment- Harry Sink (2008), "Logistics Capability, Logistics Outsourcing And Firm Performance İn An E-Commerce Market", International journal of physical distribution \& logistics management Cilt: 38, Say1: 5, ss. 336-359.

Çelik, Mazlum ve Çıra, Ahmet (2013), “Örgütsel Vatandaşık Davranışının İş Performansı ve İşten Ayrılma Niyeti Üzerine Etkisinde Aşsırı İş̧ Yükünün Aracılık Rolü”, Ege Akademik Bakış, Cilt: 13, Sayı:1, ss.1120.

Çöllü, Fazıl E. ve Summak, Erhan M. (2010), Örgütsel İletişimin Örgütsel Bağlılığa Etkisi: Konya'da Bulunan Mali Müşavir Çalışanları Üzerine Bir Araştırma. Selçuk Üniversitesi Sosyal Bilimler Meslek Yüksekokulu Dergisi, Cilt: 13, Sayı: 1-2, ss. 273-288.

Day, George S. (1994), "The Capabilities of Market-Driven Organizations”, Journal of Marketing, Cilt: 58, Say1: 4, ss. 37-52.

Demir, Şirvan ve Demir, Mahmut (2009), “Örgütsel İletişimimde Duygusal Zekânın Rolü: Konaklama İşletmelerinde Bir Araştırma”, Selçuk 
Üniversitesi İletişim Fakültesi Akademik Dergisi, Cilt. 6 Sayı:1, ss. 6777.

Demirel, Yavuz- Seçkin Zeliha ve Özçınar Faruk. M. (2011), “Örgütsel İletişim ile Örgütsel Vatandaşlık Davranışı Arasındaki İlişki Üzerine Bir Araştırma", Ç.Ü. Sosyal Bilimler Enstitüsü Dergisi, Cilt. 20 Sayı:2 ss.33-48

Elçi, Şirin (2006). İnovasyon: Kalkınmanın ve rekabetin anahtarı. Meteksan Bilişim Grubu, BT Haber.

Elmas, Neslihan ve Karabulut, A. Tuğba (2018), "Örgütsel İletişimin İş Tatmini Üzerindeki Etkisi: Otomotiv Sektöründe Bir Araştırma”, İstanbul Ticaret Üniversitesi Sosyal Bilimler Dergisi, Cilt:17, Sayı: 33, ss.209-224.

Eroğlu, Erhan (2010), “Örgütsel İletişimin İşgörenlerin Duygu Gösterimlerinin Yönetimine Olan Etkisi”, Selçuk Üniversitesi İletişim Fakültesi Akademik Dergisi, Cilt. 6, Say1: 3, ss.18-33.

Eroğluer, Kemal (2011), “Örgütsel İletişim ile İş Tatmini Unsurları Arasındaki İlişkiler: Kuramsal Bir İnceleme”, Ege Akademik Bakış, Cilt: 11, Sayı:1, ss. 121-136.

Ertekin, İrfan- Ilgın, Hicran Ö. ve Yengin, Didem A. (2017), “Örgütsel İletişim Kuramları", The Turkish Online Journal of Design Art and Communication, Cilt: 8, Say1: 2, ss.297-311.

Eyitmiş, Ahmet Melih (2016), Değer Zincirinde Bilgi Transferinin İşletme Performansına Etkisi: Kahramanmaraş Tekstil Sanayinde Bir Araştırma, Doktora Tezi, Selçuk Üniversitesi, Sosyal Bilimler Enstitüsü, Konya.

Flint, Daniel J.- Larsson Evert- Gammelgaard, Britta ve Mentzer, John T. (2005). "Logistics İnnovation: A Customer Value-Oriented Social Process", Journal of Business Logistics, Cilt: 26, Say1:1, ss. 113-147.

Geçikli, Fatma (2004), “Örgütsel İletişimin Yöneticiler Açısından Değerlendirilmesi ve Örgütsel İletişim Yönetimi”, İstanbul Üniversitesi İletişim Fakültesi Dergisi, Cilt. 20 Sayı:1, ss.107-116.

Grunig, James. E. (2005), Halkla İlişkiler ve İletişim Yönetiminde Mükemmellik. Rota Yayınları, İstanbul. 
Güllüoğlu, Özlem. (2012), “Örgütsel İletişim, iletişim Doyumu ve Kurumsal Bağlılık”, Eğitim Kitabevi, Konya

Gürbüz, Sait (2006), “Örgütsel Vatandaşlık Davranışı ile Duygusal Bağlılık Arasındaki İlişkilerin Belirlenmesine Yönelik Bir Araştırma", Ekonomik ve Sosyal Araştırmalar Dergisi, Cilt: 3, Sayı:1, ss. 48-75

Halis, Muhsin. (2000), “Örgütsel İletişim ve İletişim Tatminine İlişkin Bir Araştırma" Atatürk Üniversitesi İktisadi ve İdari Bilimler Dergisi, Cilt: 14, Say1:1, ss.217-230.

Hayes, Robert. H. ve Pisano, Gary P. (1994), "Beyond World-Class: The New Manufacturing Strategy", Harvard Business Review, Cilt.72, Sayı:1, ss.77-86.

Jahangir, Nadim-Mohammad Muzahid Akbar-Mahmudul Haq. (2004), "Organizational citizenship behavior: Its nature and antecedents", Cilt: 1, Say1: 2, ss.75-85

Karaçor, Süleyman ve Şahin, Ali (2004), “Örgütsel İletişim Kurma Yöntemleri ve Karşılaşılan İletişim Engellerine Yönelik Bir Araştırma”, SÜ İIBF Sosyal ve Ekonomik Araştırmalar Dergisi, Cilt. 4, Sayı: 7, ss.97-117.

Karaxha, Hidajet, Kristo, Illia (2016), "The Logistics and Management of Distribution Channels, the case of Kosovo", Ilıria International Review, Cilt. 6, Sayı:1, ss. 37-48.

Kayış Aliye (2014), Güvenilirlik SPSS Uygulamalı Çok değişkenli İstatistik Teknikleri, Ed. Şerif Kalaycı, Asil Yayın Dağıtım Ltd. Şti.

Kelly, Dawn (2000), "Using vision to improve organisational communication”, Leadership \& Organization Development Journal; 21, 1/2; ABI/INFORM Global, ss. 92-101

Kline, Rex. B. (2011), “Convergence Of Structural Equation Modeling And Multilevel Modeling”, ss.562-589

Kozan Gülsün. K. (2019), “Lojistik Yeteneğin Öncülleri ve Lojistik Yeteneğin Lojistik Performans Üzerindeki Etkisi”, Yayınlanmış Yüksek Lisans Tezi, Kahramanmaraş Sütçü İmam Üniversitesi Sosyal Bilimler Enstitüsü, Kahramanmaraş.

Nezakati, Hossien-Omid Asgari- Faraz Karimi-Vajihe Kohzadi (2010), "Fostering Organizational Citizenship Behavior (OCB) Through 
Human Resources Empowerment (HRE)", World Journal of Management, 2(3):47-64.

Özdevecioğlu, Mahmut (2003), “Örgütsel Vatandaşlık Davranışı ile Üniversite Öğrencilerinin Bazı Demografik Özellikleri ve Akademik Başarıları Arasındaki İlişkilerin Belirlenmesine Yönelik Bir Araştırma", Erciyes Üniversitesi İktisadi ve İdari Bilimler Fakültesi Dergisi, Say1: 20, ss.117-135.

Özdevecioğlu, Mahmut (2013), “Algılanan Örgütsel Destek ile Örgütsel Bağlılık Arasındaki İlişkilerin Belirlenmesine Yönelik Bir Araştırma", Dokuz Eylül Üniversitesi İktisadi İdari Bilimler Fakültesi Dergisi, Cilt.18, Sayı: 2, ss.113-130.

Pirttila, Timo ve Huiskonen, Janne (1996), “A Framework For Cost-Service Analysis in Differentiation of Logistics Services”, International Journal of Production Economics, Cilt. 45-3, Sayı:1, ss. 131-137.

Sabuncuoğlu, Zeyyat ve Vergiliel Tüz, Melek (2016), "Örgütsel Davranış", 6. Baskı, Alfa Aktüel Yayınları, Bursa.

Sandberg, Erik ve Abrahamsson, Mats (2011). "Logistics Capabilities For Sustainable Competitive Advantage", International Journal of Logistics Research and Applications, Cilt.14, Say1:1, ss.61-75.

Sezgin, Ferudun, (2005), “Örgütsel Vatandaşlık Davranışları: Kavramsal Bir Çözümleme ve Okul Açısından Bazı Çıkarımlar”. Gazi Üniversitesi Gazi Eğitim Fakültesi Dergisi, Cilt. 25, Sayı:1, ss. 317-339.

Sum, Chee. C., Teo, Chew. B. (1999), "Strategic Posture Of Logistics Service Providers İ́n Singapore", International Journal of Physical Distribution \& Logistics Management, Cilt. 29, Say1: 9, ss.588-605.

Taşlıyan, Mustafa ve Hırlak, Bengü (2014). “Örgütsel İletişim Etkinliği ile İş Tatmini, Örgütsel Bağlılık, Örgütsel Vatandaşlık Davranışı Arasındaki İlişkilerin Araştırılması: Akademik Örgütler İçin Bir Alan Araştırması.” Ekonomi ve Yönetim Araştırmaları Dergisi Cilt: 3, Say1: 2, ss.7-36.

Ural, Ayhan, ve Kılıç, İbrahim. (2013), Bilimsel Araştırma Süreci ve Spss ile Veri Analizi, 4. Bask1, Detay Yayınc1lık, Ankara.

Uslu, Barış, Balc1, Esergül (2012), “İlköğretim Okulu Öğretmenlerinin Örgütsel Vatandaşlık Davranışları ile Örgütsel İletişim Algıları 
Arasındaki İlişki”, Kuram ve Uygulamada Eğitim Yönetimi, Cilt. 3 Say1: 3, ss.461-489.

Uzun, Ali (2001), “Technological Innovation Activities in Turkey: The Case of Manufacturing Industry”, 1995-1997”, Technovation, Cilt. 21, Say1: 3, ss. 189-196.

Van Dick, R.-Grojean, Micheal. W.-Christ, Oliver-Wieseke, Jan (2006), "Identity and the Extra Mile: Relationships Between Organizational Identification and Organizational Citizenship Behaviour”. British Journal of Management, Cilt 17 Say1: 4, ss.283-301.

Van Riel- Cees. BM- Fombrun, Charles. J. (2007), "Essentials Of Corporate Communication: Implementing Practices For Effective Reputation Management”. Routledge.

Walz, Sandra M. ve Niehoff, Brian P. (2000), “Organizational Citizenship Behaviors: Their Relationship To Organizational Effectiveness”, Journal of Hospitality \& Tourism Research, 24(3), ss.301-319.

\section{İnternet Kaynağı}

https://www.businessmanagementideas.com/marketing/physicaldistribution/physical-distribution-definition-objectives-importance-andcomponents-marketing/17992, (Erişim Tarihi: 24.02.2020). 